\title{
Biological control of soft rot bacteria of onion in Bangladesh
}

\author{
M. M. Rahman ${ }^{1,2 *}$, A. A. Khan $^{1}$ and A. M. Akanda ${ }^{1}$ \\ ${ }^{1}$ Department of Plant Pathology, Bangabadhu Sheikh Mujibur Rahman Agricultural University, Gazipur-1706, Bangladesh \\ ${ }^{2}$ Senior Scientific Officer, Jute Research Regional Station, Faridpur, Bangladesh Jute Research Institute
}

Received: 23 May 2021

Revised: 01 September 2021

Accepted: 13 September 2021

DOI: https://doi.org/10.3329/bjsir.v56i4.57196

\begin{abstract}
An investigation was conducted to search antagonistic bacteria as biological control agents of soft rotting bacterial pathogen of onion (Allium cepa L.) in vitro and in storage. Antibacterial activity of previously isolated 91 bacterial isolates was tested in vitro against onion soft rot bacteria Burkholderia cepacia O-15. Two isolates namely, R-15 and E-37 were found antagonistic against onion soft rot bacteria. Isolate R-15 was identified as the genus Bacillus and the isolate E-37 to Lactobacillus sp. Isolate R-15 proved to be a strong antagonist against onion soft rot bacteria was selected for bio-control of onion in storage. That was also effectively reduces the soft rot disease of onion in storage condition. Percentage of disease reduction (PDR) due to treatment with antagonistic bacteria was $72.4 \%$ compared to untreated control. It is therefore suggested that this isolate could be exploited as biocontrol agent for onion soft rot in Bangladesh.
\end{abstract}

Keywords: Onion soft rot bacteria; Biocontrol; Bangladesh; Allium cepa L.

\section{Introduction}

Bacterial soft rot to onion (Allium cepa L.) caused by Burkholderia cepacia O-15 is one of the major post harvest diseases of onion. The effect of the disease is more pronounced in different countries where appropriate storage facilities are lacking (Bdliya and Haruna, 2007). Control of bacterial soft rot of vegetables is based almost exclusively on phyto-sanitary and cultural practices. Use of chemicals is generally not recommended for the control of soft rot disease (Agrios, 1997) because high risk of residual effect of chemicals on onion which might be hazardous to consumers (Yien and Sijam, 1999). Biological control is a potential method to control soft rot disease (Xu and Gross, 1986). The strategy for biological control of plant diseases involves the use of antagonistic microorganisms before or after infection takes place. Commercial biological control agents are available as seed treatments and soil amendments to protect plants against soil borne pathogens. Currently, the bacteria Bacillus subtilis and Pseudomonas spp. and the fungi Gliocladium virens and Trichoderma spp. are the organisms mostly used in biological control strategies. Potentiality of biological control of bacterial soft rot with antagonistic bacteria, or with growth promoting rhizobacteria, fluorescent pseudomonads and endophytic bacteria in many crops has been proved (Agrios, 1997; Abdelgafar and Abdelsayed, 1997; Sturz and Matheson 1996). Suppression of soft rot bacteria was attributed to the production of fluorescent siderophores that were essential for uptake of iron by the pseudomonads (Kleopper et al. 1980b). The bioagent B. subtilis was the most effective in reducing the soft rot decaying stored potato tubers (Abd-El-Khair and Karima, 2007). The importance of environment friendly plant protection methods is greatly emphasized in the sustainable agriculture. The recent increase in publication on bacterial endophytes reflects an interest in their potential benefits as biocontrol agents in agriculture (Kobayshi and Palumbo, 2000). So, the development of suitable and environment friendly control measures against soft rot causing bacteria may minimize the loss in storage and improve the quality of onion. 
In Bangladesh suitable control measures to soft rot of onion has not yet to been developed. Attempt to develop control methods against soft rot disease need to be strengthenes. Considering the above facts, the present study was undertaken with the objectives to search for biological control agents and to evaluate their efficacy against soft rot of onion in vitro and in storage.

\section{Materials and methods}

\section{Isolation of antagonistic bacteria}

Bacterial samples were isolated from rhizospheres of various crop plants, endophytes, soils, and atmosphere, and tested as antagonists to onion soft rot disease (Table I-III). The rhizosphere soil samples of potato (Solanum tuberosum L.), onion (Allium cepa L.), papaya (Carica papaya), rice (Oryza sativa), tomato (Lycopersicon esculentum), garlic (Allium sativum), zinger (Zinziber officinale) and turmeric (Curcuma longa) were collected (Table I). The soil was cleaned to remove debris and unwanted particles. Dilution plate techniques were followed and Yeast Pepton Dextrose Agar (YPDA) was used as common and basic medium. Ten gram of soil was taken from each sample was taken in a beaker and mixed thoroughly in $100 \mathrm{ml}$ distilled water on a rotary shaker (250 rpm). Then the suspension was allowed to sediment for $10 \mathrm{~min}$. After sedimentation the soil suspension was taken from the upper part and diluted to $10^{3}-10^{4}$ in distilled water. The diluted soil suspension was streaked on Petridishes containing YPDA and incubated at room temperature $\left(30^{\circ} \mathrm{C}\right)$ for 24-48 $\mathrm{h}$ in Japaneese low temperature incubator, model-IJ101. After the incubation period was over, different types of bacterial colonies appeared on the medium which were selected based on pure and identical colonies and re-streaked for pure culture. The pure culture of selected bacterial isolates was preserved in test tubes containing sterilized water for antibacterial evaluation.

To isolate endophytic bacteria, fresh and diseased plant specimens of root, stem, and leaf of various plants (Table II) including onions were collected from different locations (Table II) (AEZ no. 3, 12, 19, 28) of Bangladesh. Desired bacteria were isolated following streak-plate technique using YPDA. After 24-48 h of incubation, bacterial colonies were observed on the medium. Isolated bacterial colonies were re-streaked on YPDA media for obtaining pure culture. Colonies selected from isolation plates were transferred into test tubes containing $5 \mathrm{ml}$ sterilized distilled water. The tubes with the bacterial suspension were preserved at room temperature $\left(27-30^{\circ} \mathrm{C}\right)$.

Some bacterial isolates were collected from soil mixed with compost (garden compost) following the procedures as described in case of rhizospheric bacteria. However, air trapping method was applied to collect several bacterial isolates from the atmosphere. Three Petridishes containing YPDA were placed in the field and also in the laboratory of Bangabandu Sheikh Mujibur Rahman Agricultural University (BSMRAU) and kept opened for 5, 10, and 15 min. The petridishes were covered with the lids and incubated at room temperature $\left(27-30^{\circ} \mathrm{C}\right)$ in the Laboratory for 24-48 h. The bacterial colonies developed on the medium were re-streaked for pure culture and preserved in test tubes containing sterilized distilled water.

\section{Antagonistic activity tests}

Antagonistic activity of the probable antagonistic bacterial isolates was tested in vitro using plate chloroform method (Wakimoto et al., 1986; Furuya et al., 1997). One loop full of 1-2 days old probable antagonistic bacterial colony grown in YPDA was transferred to the center of a Petridish containing $20 \mathrm{ml}$ YPDA. The plates were incubated at $30^{\circ} \mathrm{C}$ for $2-3 \mathrm{~d}$. When the bacteria formed colonies of several millimeters in diameter, the plate was then turned upside down. A sheet of filter paper was placed in the petridish lid with $0.5 \mathrm{ml}$ chloroform. The dish was kept at room temperature for $2 \mathrm{~h}$. After completing the evaporation of chloroform vapor, $5 \mathrm{ml}$ suspension of indicator bacteria $\left(\mathrm{ca} .10^{8} \mathrm{cfu} / \mathrm{ml}\right)$ was overlaid on each plate. Here soft rot bacteria, B. cepacia O-15 were used as indicator bacteria. The plate thus prepared was incubated at $30^{\circ} \mathrm{C}$ for $2 \mathrm{~d}$. When an inhibition zone appeared, its diameter was measured to evaluate the antibacterial activity of the probable antagonistic bacteria (Furuya et al., 1997). The bacterial isolates which showed antagonistic effects against indicator soft rot bacteria were selected for further study.

\section{Biological control of onion soft rot disease in storage condition}

To evaluate the effectiveness of the selected antagonistic bacteria in reducing soft rot infection in storage, $700 \mathrm{~g}$ fresh onion bulbs (cultivar Faridpuri) were used in the test. Fresh onion bulbs were dipped in suspensions of antagonistic bacteria R-15 (ca. of $10^{7}-10^{8} \mathrm{cfu} / \mathrm{ml}$ ), for $30 \mathrm{~min}$ and air dried. The treated onion bulbs were inoculated with $B$. cepacia $\mathrm{O}-15$, by spraying with inoculum supensions $\left(10^{7}-10^{8} \mathrm{cfu} / \mathrm{ml}\right)$ with an atomizer. Inoculated onion bulbs were air dried at room temperature and stored separately in net bags at sterilized condition in a sterilized room and maintained room temperature $\left(27-30^{\circ} \mathrm{C}\right)$ naturally. Data on soft rot incidence was recorded after 2, 6, 10, 14, 18, and 22 weeks of inoculation. Number and weight of soft rot infected bulbs were recorded and expressed in percentage using the following formula (Abd- El-Khair and Karima, 2007). 
Percentage of disease reduction (PDR) was calculated according to Hajhamed et al. (2007).

$$
\text { infection } \%=\frac{\text { No. of infected bulbs }}{\text { Total no. of bulbs }} \times 100
$$

Loss of weight $\%=\frac{\text { Initial weight }- \text { weight after discarded the infected sample }}{\text { Initial weight }} \times 100$

Percentage of disease reduction (PDR) was calculated according to Hajhamed et al. (2007).

$$
\mathrm{PDR}=\frac{\text { Ack }- \text { Atr }}{\text { Ack }} \times 100
$$

where, Ack $=$ disease severity in control and Atr $=$ disease severity in treatment

\section{Characterization and identification of antagonistic bacterial isolates}

Preliminary characterization of the selected antagonistic bacterial isolates was performed by a series of physiological and biochemical tests. The tests were: potato soft rot (Perombelon et al., 1979), gram reaction (Suslow et al., 1982), growth at $37^{\circ} \mathrm{C}$, growth in $5 \% \mathrm{NaCl}$ (Schaad, 1980; Dye, 1969), catalase production (Hayward, 1992), oxidase reaction, nitrate reduction (Hayward, 1992), methyl red test (Dye, 1969), arginine utilization (Thornley, 1960), gas formation (Hugh and Leifson, 1953), levan formation (Goszczynska et al., 2000), and tobacco hypersensitivity reaction (Klement and Goodman, 1967). Carbon source utilization tests were performed using Ayer's media (Ayer et al., 1919).

\section{Results and discussion}

\section{Isolation of probable antagonistic bacterial isolates}

In the present experiment, a total of 91 isolates of probable antagonistic bacteria were obtained from different sources. Among 91 isolates of probable antagonistic bacteria 28 isolates were from rhizosphere soil of nine crops viz., potato, onion, papaya, rice, tomato, garlic, zinger, and turmeric. And the samples were collected from the BSMRAU campus and Bangladesh Agricultural Research Institute (BARI), Rangpur. The number of endophytic bacterial isolates, collected from 13-plant species, compost fertilizers, atmosphere, and from the stock of microbiology laboratory of BSMRMAU were 44,
4,3 , and 12 , respectively. The host organs, locations and time of isolation, media used for isolation and colony characters have been presented in Tables I - III. We assumed that numerous antagonistic bacteria are present in nature and in plant and soil samples on the basis of many research works (Agrios, 1997; Abdelgafar and Abdelsayed, 1997; Sturz and Matheson, 1996). So these sources were selected for probable antagonistic bacterial isolates.

Antagonistic activity of 91 isolates against onion soft rot bacteria in vitro

Among 91 bacterial isolates tested for antagonistic activity, only two isolates namely, R-15 isolated from potato rhizosphere, and E-37 isolated from endophyte of marigold ( $T$. erecta) was found antagonistic against $B$. cepacia O-15 (Table I-III). Distinct inhibition zone was observed around the colonies of antagonistic bacteria (Figure 1). The diameter of the inhibition zones around antagonistic bacterial colonies ranged from 5-11 mm (Table IV) indicating the variability in production of antibacterial substances. Isolate $\mathrm{R}-15$ was a strong antagonist against soft rot bacteria of onion. So it was tested for biological control of onion soft rot bacteria B.cepacia $\mathrm{O}-15$ in storage.

In vitro experiment for searching antagonistic bacteria against soft rot bacterial pathogens demonstrated that there are some antagonistic bacteria, which possess the ability to inhibit the growth of plant pathogenic bacteria. The antibacterial activity varied greatly, depending upon the various antagonists, type, and number of antibacterial substances such as Pyrrolnitrin, DAPG, Phenazines, Oomycin A, Pyoluteorin, etc (Raaijmakers et al., 2002) produced by them. Those and many other studies have shown that bacterial biocontrol strains not only exhibit a wide range of diversity in the type but also in the number of antibiotics produced. It also indicated that several antibiotics participated in the formation of inhibition zone.

Effect of onion bulb treatment with antagonistic bacteria on soft rot in storage

The effects of antagonistic bacteria (R-15) on soft rot incidence of onion in storage at different time intervals are shown in Figure 2. At the $2^{\text {nd }}$ week of the experiment, no infection was occurred but started from $6^{\text {th }}$ week of inoculation. At the $22^{\text {th }}$ week, the infection of onion bulbs 
Table I. List of probable antagonistic bacteria (28) isolated from rhizosphere of various crops and tested for antagonistic activity against soft rot bacteria of onion

\begin{tabular}{|c|c|c|c|c|}
\hline $\begin{array}{l}\text { Isolates } \\
\text { No. }\end{array}$ & $\begin{array}{c}\text { Sources } \\
\text { (Rhizosphere of) }\end{array}$ & Locations & $\begin{array}{c}\text { Colony characters on } \\
\text { YPDA }\end{array}$ & $\begin{array}{l}\text { Antagonistic } \\
\text { activity }\end{array}$ \\
\hline R-1 & Papaya (Carica papaya L.) & Rangpur & Yellow & - \\
\hline $\mathrm{R}-2$ &, &, & Creamy white & - \\
\hline $\mathrm{R}-3$ & Rice (Oryza sativa L.) & " & White & - \\
\hline $\mathrm{R}-4$ &, & , & Creamy white & - \\
\hline $\mathrm{R}-5$ &, & , & White & - \\
\hline $\mathrm{R}-6$ & Potato (Solanum tuberosum L.) & , & White dry & - \\
\hline $\mathrm{R}-7$ & " & , &, & - \\
\hline $\mathrm{R}-8$ & , & , & White sticky & - \\
\hline R-9 & , & , & White & - \\
\hline $\mathrm{R}-10$ & , & , & , & - \\
\hline R-11 & ", & ", & Creamy white sticky & - \\
\hline $\mathrm{R}-12$ & ", & ", & Very small white & - \\
\hline $\mathrm{R}-13$ & " & , & White & - \\
\hline $\mathrm{R}-14$ & , & BSMRAU & White big & - \\
\hline R-15 & , & , & White & + \\
\hline $\mathrm{R}-16$ & , &, & White sticky & - \\
\hline $\mathrm{R}-17$ & , & BARI & Yellow white & - \\
\hline R-18 & " &, & White smal & - \\
\hline R-19 &, & , & White big & - \\
\hline $\mathrm{R}-20$ & $\begin{array}{l}\text { Tomato (Lycopersicon esculentum } \\
\text { (L.) Karst.) }\end{array}$ & ” & White & - \\
\hline $\mathrm{R}-21$ &, & , & Yellow & - \\
\hline $\mathrm{R}-22$ & , & " & Creamy white & - \\
\hline $\mathrm{R}-23$ & Onion (A. сера) & , & White big & - \\
\hline $\mathrm{R}-24$ & , & BSMRAU & White & - \\
\hline $\mathrm{R}-25$ & Garlic (Allium sativum L.) & BARI & White big & - \\
\hline $\mathrm{R}-26$ & Zinger (Zinziber officinale Rosc.) &, & White & - \\
\hline $\mathrm{R}-27$ & Turmeric (Curcuma longa L.) & , & White big & - \\
\hline R-31 & Tomato (L. esculentum) & BSMRAU & White big & - \\
\hline
\end{tabular}

BARI= Bangladesh Agricultural Research Institute

reached up to $25.6 \%$. While in case of untreated control infection started before $2^{\text {nd }}$ week and reached up to $100 \%$ within 18 weeks (Figure 2).

The percentages of loss (in weight) of onion were shown in Figure 3. It was found that the weight losses were always higher in untreated control than treated one during the whole period of storage. At the $22^{\text {th }}$ weeks of storage, $27.6 \%$ loss (in fresh weight of onion bulbs) was recorded in treated sample while it was $100 \%$ in untreated control. So, percentage of disease reduction (PDR) was $72.4 \%$ compared to untreated control (Figure 3 ).

Characterization and identification of antagonistic bacterial isolates

In the potato soft rot and oxidase tests, both the two isolates of the antagonistic bacteria were found gram positive and negative in catalase reactions. The isolate R-15 grew well at 
Table II. List of probable antagonistic bacteria (44) isolated from endophytes of various crops and tested for antagonistic activity against soft rot bacteria of onion

\begin{tabular}{|c|c|c|c|c|}
\hline $\begin{array}{l}\text { Isolates } \\
\text { No. }\end{array}$ & Sources/(Endophytes of) & Locations & $\begin{array}{l}\text { Colony characters } \\
\text { on YPDA }\end{array}$ & $\begin{array}{l}\text { Antagonistic } \\
\text { activity }\end{array}$ \\
\hline E-35 & Cheerota (Swertia chiraita Ham.) & BSMRAU & White & - \\
\hline E-36 &, & , & Creamy white & - \\
\hline E-37 & Marigold (Tagetis erecta L.) & 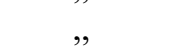 & White & + \\
\hline E-38 & , & 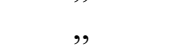 & Creamy White & - \\
\hline E-39 & Katabegun (Solanum carolinense L.) & ,, & Yellowish White & - \\
\hline E-40 & Ghritokumari (Aloe barbadensis Mill.) & , & Creamy White & - \\
\hline E-41 & , & , & Yellow & - \\
\hline E-42 & , & 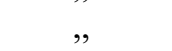 & White & - \\
\hline E-43 & Taro (Colocasia esculenta (L.) Schott.) & 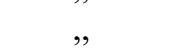 & Yellow & - \\
\hline E-44 & Tomato (L. esculentum) & , & Yellow White & - \\
\hline E-45 & Papaya (C. papaya) & , & White small & - \\
\hline E-46 & Onion $(A$. cepa $)$ & $"$ & Yellow & - \\
\hline E-47 & , & , & White & - \\
\hline E-48 & Garlic (A. sativum) & , & Creamy White & - \\
\hline E-49 & , & 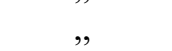 & Yellowish White & - \\
\hline E-50 & Bilimbi (Averrhoa bilimbi L.) & 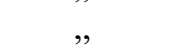 & Very small White & - \\
\hline E-51 & Onion $(A$. cepa $)$ & Pabna & White & - \\
\hline E-52 & , &, & White & - \\
\hline E-53 & 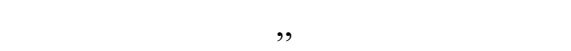 & 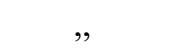 & White & - \\
\hline E-54 & ", &, & White & - \\
\hline E-55 & Potato (S. tuberosum) & Rangpur & White big & - \\
\hline E-56 & , &, & White big & - \\
\hline E-57 & $"$ & 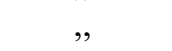 & Creamy White & - \\
\hline E-62 & Balsam (Impatiens balsamina L.) & 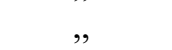 & Very small White & - \\
\hline E-63 & $\begin{array}{l}\text { Elephant foot yam (Amorphophallus } \\
\text { paeoniifolius (Dennst.) Nicolson) }\end{array}$ & $"$ & Creamy White & - \\
\hline E-64 & Tomato (L. esculentum) & , & Creamy White & - \\
\hline E-65 & Potato (S. tuberosum) & Gazipur & White & - \\
\hline E-66 & , &, & White & - \\
\hline E-67 & 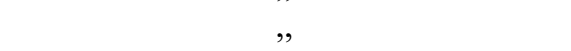 & , & Creamy White & - \\
\hline E-68 & 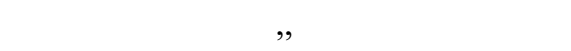 & $"$ & White & - \\
\hline E-69 & 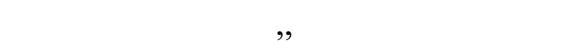 &, & White small & - \\
\hline E-70 & 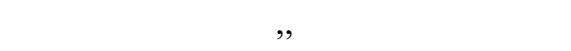 & 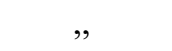 & $"$ & - \\
\hline E-71 & , & , & , & - \\
\hline E-72 & Indian onion (A. серa) & $"$ & White & - \\
\hline E-73 & , & 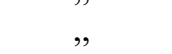 & White & - \\
\hline E-74 & $"$ & $"$ & White sticky & - \\
\hline E-75 & $"$ & $"$ & White small & - \\
\hline E-76 & 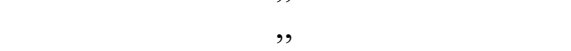 & 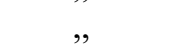 &, & - \\
\hline E-77 & " &, & White dry & - \\
\hline E-78 & Deshi onion $(A$. серa $)$ & BARI & White & - \\
\hline E-79 & Potato (S. tuberosum) & Dhaka & White & - \\
\hline E-80 & , &, & White small & - \\
\hline E-81 & $"$ & 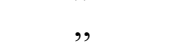 & White & - \\
\hline E-82 & $"$ & 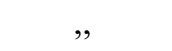 & White & - \\
\hline
\end{tabular}


Table III. List of probable antagonistic bacteria (19) isolated from compost fertilizer, atmosphere and Laboratory of BSMRAU and tested for antagonistic activity against soft rot bacteria of onion

\begin{tabular}{|c|c|c|c|c|}
\hline $\begin{array}{l}\text { Isolates } \\
\text { No. }\end{array}$ & Sources & Locations & $\begin{array}{c}\text { Colony characters on } \\
\text { YPDA }\end{array}$ & $\begin{array}{c}\text { Antagonistic } \\
\text { activity }\end{array}$ \\
\hline C-28 & Compost & BARI & White & - \\
\hline C-29 &, &, & White big & - \\
\hline C-30 & , &, & White & - \\
\hline C-58 & , & BSMRAU & White big & - \\
\hline A-59 & Air trapping & , & Redish & - \\
\hline A-60 &, & , & Creamy white & - \\
\hline A-61 & , & , & White dry & - \\
\hline L-85 & Lab isolate & Microbiology lab. & White big & - \\
\hline L-86 & , &, & Yellow big & - \\
\hline L-87 & , & , & White big & - \\
\hline L-88 & , & , & White & - \\
\hline L-89 & , & , &, & - \\
\hline L-90 & , & , & , & - \\
\hline L-91 & " & ", & White big & - \\
\hline L-92 & , & , &, & - \\
\hline L-93 & " & , & Very small white & - \\
\hline L-94 & $"$ & , & White big & - \\
\hline L-95 & $"$ & , &, & - \\
\hline L-96 & , & ", & White big & - \\
\hline
\end{tabular}

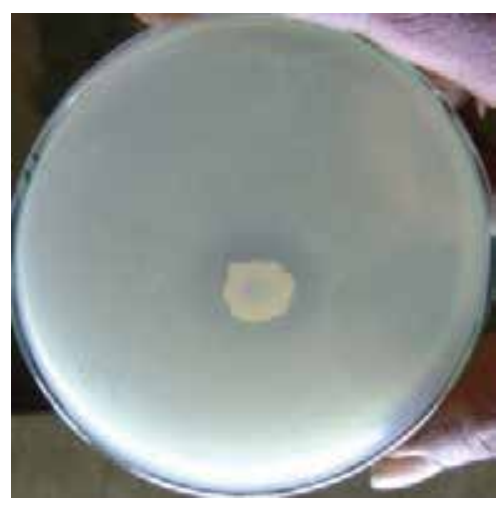

A

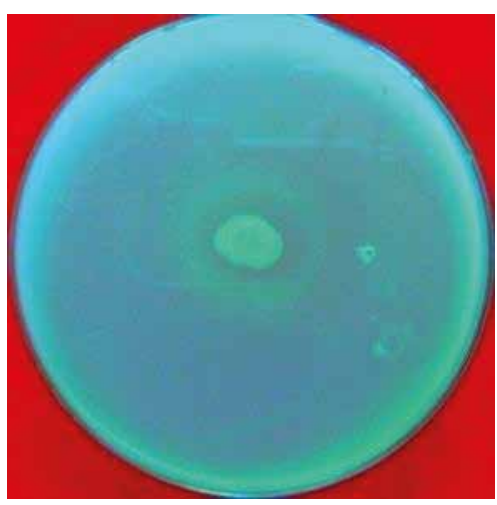

$\mathrm{B}$

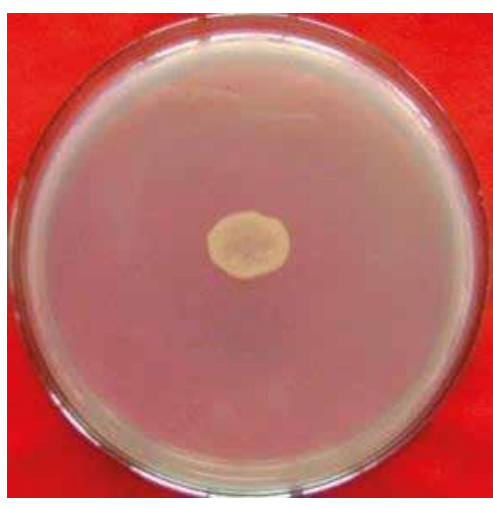

C

Fig. 1. Antagonistic activity of isolates R-15 showing inhibition zones against onion soft rot bacteria Burkholderia cepacia 0-15 (A and B) positive reaction; (C) No inhibition zone (negative reaction) 
Table IV. Antagonistic bacteria with their effectivity against soft rot bacteria of onion (B. cepacia O-15)

\begin{tabular}{cc}
\hline $\begin{array}{c}\text { Name of antagonistic } \\
\text { isolates }\end{array}$ & $\begin{array}{c}\text { Width of inhibition zone (mm) }{ }^{\mathrm{a}} \text { against } \\
\text { Onion soft rot bacteria (Burkholderia cepacia) }\end{array}$ \\
\hline E 37 & $++(5)$ \\
R-15 & $+++(11)$ \\
\hline
\end{tabular}

anhibition zone diameter index: + = inhibition zone positive; - = inhibition zone negative;

$+++=10 \mathrm{~mm}$ to above, $++=$ below $10 \mathrm{~mm}$, Figures in parentheses indicates diameter of inhibition zones in millimeter.

Table V. Physiological and biochemical characteristics of antagonistic bacteria R-15 and E-37

\begin{tabular}{|c|c|c|c|c|}
\hline \multirow[t]{2}{*}{ Name of Tests } & \multicolumn{2}{|c|}{ Antagonistic isolates } & \multirow[t]{2}{*}{ *Bacillus sp. } & \multirow[t]{2}{*}{$\begin{array}{c}{ }^{*} \text { Lacto- } \\
\text { bacillus sp. }\end{array}$} \\
\hline & $\mathrm{R}-15$ & E-37 & & \\
\hline Potato soft rot & - & - & - & - \\
\hline Gram reaction & + & + & + & + \\
\hline Growth at $37^{\circ} \mathrm{C}$ & + & $\mathrm{w}^{+}$ & + & + \\
\hline Growth in $6.5 \% \mathrm{NaCl}$ & + & $\mathrm{w}^{+}$ & + & NA \\
\hline Catalase & - & - & - & - \\
\hline Oxidase & - & - & - & - \\
\hline Nitrate reduction & $\mathrm{w}^{+}$ & + & + & + \\
\hline Arginine utilization & - & - & NA & NA \\
\hline Gas formation & - & $\mathrm{w}^{+}$ & - & $\mathrm{w}^{+}$ \\
\hline Flurescent pigment on K'B & - & - & - & - \\
\hline Tobacco hypersensitivity & - & - & - & - \\
\hline
\end{tabular}

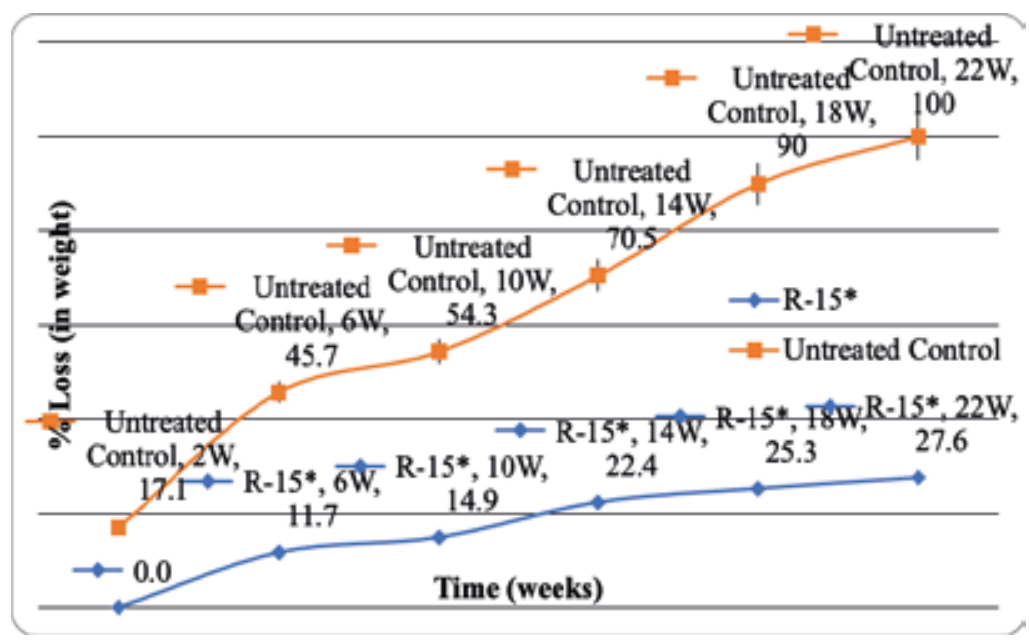

Fig. 2. Effect of antagonistic bacteria (R-15) on soft rot disease incidence of onion in storage condition at 4 weeks $(W)$ of intervals 
$37^{\circ} \mathrm{C}$ and in $6.5 \% \mathrm{NaCl}$ but the isolate E-37 grew weakly in both at $37^{\circ} \mathrm{C}$ and $6.5 \% \mathrm{NaCl}$. In nitrate reduction test, isolates R-15 showed weak positive reaction with the development of orange-brown color but isolate E-37 showed clear positive reaction. Both the isolates showed negative reaction in arginine utilization test too. No gas formation was found in case of isolate R-15. The two isolates were negative in production of fluorescent pigment on King's B medium and tobacco hypersensitivity test (Table V).

Isolates R-15 did not utilize cellobiose, lactose, maltose, L-arabinose, D-galactose, D-xylose, raffinose, sucrose and trehalose but positive in benzoete and D-tartrate. While the isolate E-37 utilized cellobiose, maltose, L-arabinose,
D-galactose, D-xylose, raffinose and sucrose but negative in lactose, benzoate and D-tartrate (Table VI and VII).

The results of the present study demonstrated that the antagonistic bacteria can inhibit the growth of soft rot bacteria in vitro and in storage. The pre-treatment of onion bulbs with antagonistic bacteria are able to prevent the initial infection and reduce soft rot disease of onion and multiplication of soft rot bacteria. Many researchers reported that antagonistic endophytic and rhizospheric bacteria observed antagonistic activity against plant pathogenic bacteria including soft rotting Erwinia (Long et al., 2003; Sharga and Lyon, 1998; Olivera et al., 2006; Raju et al., 2006; Abd- El-Khair and Karima, 2007). In a study, Long et al. (2003) reported that the genus Bacillus and fluorescent

Table VI. Utilization of different sugar as source of carbon by antagonistic bacteria R-15 and E-37

\begin{tabular}{|c|c|c|c|c|}
\hline \multirow{2}{*}{ Name of carbon sources } & \multicolumn{2}{|c|}{ Antagonistic isolates } & \multirow[t]{2}{*}{ *Bacillus sp. } & \multirow[t]{2}{*}{${ }^{*}$ Lactobacillus sp. } \\
\hline & R-15 & E-37 & & \\
\hline Cellubiose & - & + & $+/-$ & NA \\
\hline Lactose & - & - & $+/-$ & NA \\
\hline Maltose & - & + & $+/-$ & NA \\
\hline L-Arabinose & - & + & - & + \\
\hline D-Galactose & - & + & - & + \\
\hline D-Xylose & - & + & $+/-$ & NA \\
\hline Raffinose & - & + & $+/-$ & NA \\
\hline Sucrose & - & + & $+/-$ & NA \\
\hline Trehalose & - & + & $+/-$ & NA \\
\hline
\end{tabular}

*=According to Kreigh and Holt 1984 (Bergey's manual) and Long et al. (2003)

$+=$ growth positive; $-=$ negative; $\mathrm{d}+=$ delay positive; $\mathrm{NA}=$ Not available

Table VII. Utilization of different alcohols and organic acids by antagonistic bacteria R-15 and E-37

\begin{tabular}{lccccc}
\hline \multirow{2}{*}{$\begin{array}{l}\text { Name of carbon } \\
\text { sources }\end{array}$} & \multicolumn{2}{c}{ Antagonistic isolates } & & $*$ Bacillus sp. & *Lactobacillus sp. \\
\cline { 2 - 4 } & $\mathrm{R}-15$ & $\mathrm{E}-37$ & $\mathrm{~V}$ & $+/-$ \\
\hline Dulcitol & - & $\mathrm{d}+$ & - & $+/-$ \\
Inositol & - & + & - & $+/-$ \\
Manitol & - & + & + & - & $+/-$ \\
Sorbitol & - & - & + & - \\
Benzoate & + & - & + & - \\
D- Tartrate & + & - & & \\
\hline
\end{tabular}

*= According to Kreigh and Holt 1984 (Bergey's manual) and Long et al. (2003);

$+=$ Growth positive; - = negative; $\mathrm{d}+=$ delay positive; $\mathrm{v}=$ variable reaction;

NA $=$ Not available 
pseudomonads have antagonistic activity against various plant pathogenic bacteria including soft rot bacteria $E$. carotovora subsp. Carotovora in vitro. The ability of these isolates to suppress the growth of various phytopathogenic bacteria makes them potential biocontrol agents.

In the present study, the identified bacteria was Bacillus sp. and observed antagonistic activity against onion soft rot pathogen Burkholderia cepacia O-15 and also found effective against soft rot disease of onion in storage. Bacillus sp. was used by many researchers for a successful control of soft rot bacteria (Sharga and Lyon, 1998; Olivera et al., 2006; Abd- El-Khair and Karima, 2007). The results of the present experiment agreed with the previous findings. Therefore, the pre-treatment of onion bulbs with biocontrol-agents can prevent initial infection of soft rot disease and multiplication of soft rot pathogen. However, in the present study, only 700 $\mathrm{g}$ onion bulbs were treated with the antagonists. The efficacy of the antagonistic bacteria needs to be tested using large number of bulbs before recommendation.

For the screening of antagonistic bacteria to perform biological control of identification of soft rot bacteria of B.cepacia $\mathrm{O}-15$, an agent to cause onion (Allium cepa L.) soft rot disease, the physiological, biochemical and carbon sources utilization tests were done. Out of 91 sample sources, two antagonistic bacterial isolates R-15 and E-37 were suggested. The first isolate did belong to the genus Bacillus and the second one to Lactobacillus sp. However, comprehensive study is necessary for further identification of these bacteria up to the species level.

\section{Conclusion}

Aantibacterial activity of the isolated probable antagonistic bacteria was tested in vitro against previously identified onion soft rot bacteria Burkholderia cepacia O-15. Only two isolates namely, R-15 and E-37 showed antagonistic activity against onion soft rot bacteria in vitro and in storage. Isolate R-15 was identified as member of the genus Bacillus and the isolate E-37 was Lactobacillus sp. Isolate R-15 was strong antagonist against onion soft rot bacteria $B$. cepacia $\mathrm{O}-15$. That was also effectively reduces the soft rot disease of onion in storage condition.

\section{Acknowledgement}

The authors are grateful to Ministry of Science and Information \& Communication Technology, Bangladesh, for assistance by providing (NSICT) fellowship to conduct the study smoothly.

\section{References}

Abdelgafar NY and Abdelsayed WM (1997), Biological control of bacterial soft rot of potato by using flurescent pseudomonads, Arab Universities J. Agril. Sci. 5(2): 419-431. DOI: org/10.1016/S02612194(03)00030-9

Abd-El-Khair H and Karima HEH (2007), Application of some bactericides and bioagents for controlling the soft rot disease in potato, Res. J. Agric. and Bio. Sci. 3(5): 463-473.

Agrios GN (1997), Control of plant diseases In: Plant Pathology, $4^{\text {th }}$ Ed. Academic Press, California, pp 200-216. DOI: org/10.1016/C2012-0-01423-8

Ayers SH, Rupp P and Johnson WT (1919), A study of the alkali forming bacteria in milk, U. S. Dept. Agric. Bull. 782.

Bdliya BS and Haruna HU (2007), Efficacy of solar heat in the control of bacterial soft of potato tubers caused by Erwinia carotovora subsp, Carotovora, J. Plant Protec. Res. Nigeria 47(1): 11-18.

Dye DN (1969), A taxonomic study of the genus Erwinia. 1. The amylovora group, New Zealand J. Sci. 11: 590-607.

Furuya N, Yamasaki S, Nishioka M, Shirasshi I, Ityama K and Matsuyama N (1997), Antibacterial activities of pseudomonads against plantpathogenic organisms and efficacy of Pseudomonas aeruginosa ATCC7700 against bacterial wilt of tomato, Ann. Phytopathol. Soc. Japan 63: 417-424. DOI: $\quad$ org/10. 3186/jjphytopath.63.417

Goszczynska T, Serfontein JJ and Serfontein S, (2000), Introduction to Practical Phytobacteriology, SAFRINET, the Southern African (SADC) Loop of BioNet-International.

Hajhamed AA, Sayed WMAE, Yazied AAE and Ghaffar NYAE (2007), Suppression of Bacterial Soft Rot Disease of Potato, Egypt J. Phytopathol. 35(2): 69-80.

Hayward AC (1992), Identification of Pseudomonas solanacearum, In SAVERNET Bacterial Wilt Training Course held on October 5 to November 16 AVRDC, p 101. 
Hugh R and Leifson E (1953), The taxonomic significance of fermentative versus oxidative metabolism of carbohydrates by various gram-negative bacteria, $J$. Bacteriol 66: 24-26.

Klement A and Goodman R (1967), The hypersensitive reaction to infection by bacterial plant pathogens, Ann. Rev. Phytopathol. 5: 17-44.

Kloepper JW, Leong J, Teintze M and Schroth MN (1980b), Enhanced plant growth by siderophores produced by plant growth promoting rhizobacteria, Nature (Lond.) 286: $885-886$.

Kobayashi DY and Palumbo JD (2000), Bacterial endophytes and their effects on plants and uses in agriculture, In: Hb Microbial endophyies Eds. Bacon CW and White JF, Marcel Dekker, Inc., New York, N. Y, pp 99-233.

Long HH, Furuya N, Kurose D, Takeshita M and Takanami Y (2003), Isolation of Endophytic Bacteria from Solanum sp. and their antibacterial activity against plant pathogenic bacteria, J. Fac. Agr., Kyushu Univ. 48(1-2): 21-28.

Olivera FC, Caron GR, Motta AS, Souto AA and Brandelli A (2006), Bacteriocin-like substance inhibits potato soft rot caused by Erwinia carotovora, Can. J. Microbiol. 52(6): 533-539. DOI: org/10.1139/w05-159

Pérombelon MCM, Gullings-Handley $\mathrm{J}$ and Kelman A (1979), Population dynamics of Erwinia carotovora and pectolytic clostridia in relation to decay of potatoes, Phytopathology 69: 167-73.

Raaijmakers JM, Vlami M and T de Souza J (2002), Antibiotic production by bacterial biocontrol agents, Antonie van Leeuwenhoek, Kluwer Academic Publishers, Printed in the Netherlands 81: 537-547.

Raju MRB, Vijai P and Jalali I (2006), Antagonistic rhizospheric bacteria for management of bacterial soft rot of radish seed crop, Ann. of Plant Protec. Sci. India. 14(2): 393-395.

Schaad NW (1980), Laboratory guide for identification of plant pathogenic bacteria, Bacteriol. Commit. Amr. Phytopath. Soc. Minesota.

Sharga BM and Lyon GD (1998), Bacillus subtilis BS 107 as an antagonist of potato blackleg and soft rot bacteria, Can. J. Microbiol. 44(8): 777-783. DOI: org/10.1139/w98-064

Sturz AV and Matheson BG (1996), Populations of endophytic bacteria which influence host-resistance to Erwinia induced bacterial soft rot in potato tubers, Plant and Soil 184(2): 265-271.

Suslow TV, Schroth MN and Isaka M (1982), Application of a rapid method for Gram differentiation of plant pathogenic and saprophytic bacteria without staining, Phytopathol. 72: 917-98.

Thornley MJ (1960), The differentiation of $P$. solanacearum from other gram-negative bacteria on the basis of agrinine metabolism, J. App. Bacteriol. 23: 37-52.

Wakimoto S, Hirayae K, Tsuchiya K, Kushima Y, Furuya N and Matsuyama N (1986), Production of antibiotics by plant pathogenic pseudomonads, Ann. Phytopath. Soc. Jpn. 52: 835-842. DOI: org/10.3186/ jjphytopath. 52.835

Xu GW and Gross DC (1986), Selection of fluorescent pseudomonads antagonistic to Erwinia carotovora and suppressive of potato seed piece decay, Phytopathology 76: 414-422.

Yien ATS and Sijam K (1999), Biological control of bacterial soft rot of cabbage, Symposium on Biological Control in the Tropics, MARDI Trainig Centre 18-19, March, Malaysia. DOI: org/10.1016/ j.biocontrol. 2009.05.001 